\title{
EXPLORING BROWN AND LEVINSON'S POLITENESS THEORY AND THE FORM-FUNCTION FIT IN REQUESTS IN JANE AUSTEN'S PRIDE AND PREJUDICE FROM A RELEVANCE-THEORETIC, CONSTRUCTIONIST, AND CONTRASTIVE PERSPECTIVE
}

\author{
Elena del Carmen Martínez López, Independent Scholar \\ Email: elena290114@gmail.com
}

Received: June 7, 2021

Accepted: September 15, 2021

\begin{abstract}
The aim of this work is to demonstrate and illustrate the pervasive existence of points of convergence between literature and language in general and form and meaning in particular. Specifically, the connection between language and literature is explored with specific reference to one of the germinal works of English literature, Jane Austen's Pride and Prejudice in the light of the principles and taxonomies of Brown and Levinson's Politeness Theory, with special focus on requests. A further twist added to the analysis presented in this work comes from a relatively fine-nuanced contrastive (English-Spanish) analysis of requests strategies using as the database of analysis a Spanish translation of Jane Austen's Pride and Prejudice (Rodríguez, 2018).

Keywords: Politeness Theory, Pride and Prejudice, Requests, Contrastive Analysis, Construction Grammar(s).

Resumen: El propósito de este trabajo es demostrar e ilustrar la existencia de puntos de convergencia entre la literatura y el lenguaje en general, así como la forma y el significado en particular. En concreto, se explora el vínculo existente entre lengua y literatura con referencia específica a una de las obras germinales de la literatura inglesa, Pride and Prejudice de Jane Austen, en función a los principios y taxonomías que forjan la Teoría de la Cortesía de Brown y Levinson, con especial atención a las peticiones. Un valor añadido al análisis presentado en este trabajo proviene del análisis contrastivo (inglés-español) relativamente preciso de las estrategias de peticiones utilizando como base de análisis una traducción al español de Pride and Prejudice de Jane Austen (Rodríguez, 2018).

Palabras clave: Teoría de la Cortesía, Pride and Prejudice, Peticiones, Análisis Contrastivo, Gramática(s) de Construcciones.
\end{abstract}




\title{
1 INTRODUCTION AND JUSTIFICATION
}

\author{
"Events do not take place simply because of words, or via \\ speech, or through the medium of language; rather, utterance \\ and writing are the events. Speech is an act: speech acts" \\ (Nolan-Grant 2009: 863).
}

Although sometimes regarded as a secondary element when reading a literary work, language should be as on a par with other elements such as the plot or characters. Indeed, it is often acknowledged that only by doing so can we provide a principled account of the symbiotic relationship between these two language and literature (Fischer and Nänny 2001).

The aim of this work, therefore, is to demonstrate that language should be recognized as playing a pivotal element within the plot of a novel, in this case Pride and Prejudice (1813), since "any verbal behavior is goal-directed" (Jakobson 1960: 351) and, as a consequence, it contributes directly to the development of the events. To this end, the coverage and treatment of the use of requests in Brown and Levinson's Politeness Theory is the main theoretical orbit around which this project gravitates so as to provide a more principled, fine-grained understanding of the intentional use and interpretation of language in literary works.

In much the same vein, and with the intention of not only using a theoretical framework but also a practical procedure, the second part of this work outlines a syntactic and semantico-pragmatic contrastive (English-Spanish) analysis of selected instances of requests from a constructionist perspective based on Jane Austen's original English novel and its Spanish recreation by Ana $\mathrm{M}^{\mathrm{a}}$ Rodríguez (2018). At a higher level of delicacy, this contrastive analysis is aimed to illustrate, albeit briefly, some of the differences and analogies between these two languages, thus providing evidence of the meaningfulness of the choice of specific words and constructions in a literary context. Finally, the contrastive analysis proposed here is compatible with Boas' proposal of a "bottom-up" approach to the analysis of linguistic constructions, where meaning is assigned a central role in linguistic description and explanation, in line with Construction Grammar(s) (Goldberg 2006, among others) and the FrameNet project in particular (Boas 2010).

\section{METHODOLOGY}

The first sections of this paper investigate the exploitation of requests in Jane Austen's Pride and Prejudice (1813) in the light of Brown and Levinson's Politeness Theory (1987) as the main theoretical framework for the analysis of the data obtained. To this end, the database of the present work consists of 11 conversational excerpts taken manually from Jane Austen's original novel. The criteria followed for the manual selection of these excerpts are directly connected with the presence of patterns/constructions encoding requests within the novel, which in turn serve as the test bed for the application of the theoretical principles as well as the taxonomies proposed within Brown and Levinson's Politeness Theory.

Given that politeness in general and requests in particular exhibit different syntactic and semantico-pragmatic structures in English and Spanish, I would like to use a Spanish translation of Pride and Prejudice (Rodríguez 2018) as the main corpus to obtain empirical 
evidence of similarities and/or differences in the morphosyntactic encoding and semanticopragmatic interpretation of requests when recreating the English text into Spanish. To this end, I have chosen Ana M ${ }^{a}$ Rodríguez's translation of Pride and Prejudice (2018), among other reasons, because this translator (re)creates the Spanish version of this literary masterpiece in a very accurate way. Selected instances of the Spanish translation will be used to explore the main analogies and/or differences in the expression and interpretation of requests in English and Spanish from a constructionist perspective.

\section{POLITENESS THEORY}

Communication, whose definition has traditionally been associated with the capacity of transmitting information, is the basis of today's society. However, as many linguists have pointed out, communication not only serves to convey a message but also involves the development of social relations and behaviour in an interactional setting. Regarding the latter, as Watzlawick et al. (1967) suggest, it should be accepted that "all behaviour ... has message value, i.e., communication" and therefore, "it follows that no matter how one may try, one cannot not communicate. Activity or inactivity, words or silence all have message value: they influence others and these others, in turn, cannot not respond to these communications and are thus themselves communicating" (49). In the light of this, they propose that in the communication's recipe, there are two major ingredients: the 'content of the message' and the 'relationship between the communicants'. The former has to do with the "report aspect of a message", whereas the latter, referred to as "the command aspect" (51-52), deals with the effects and impact that the message conveyed has on the other person.

In much the same vein, Brown and Yule (1983) argue that language has two main functions: (i) the interactional or "listener-oriented" (13) function, whose principal interest is "to communicate friendliness and goodwill, and to make participants feel comfortable and unthreatened" (Spencer-Oatey 2008: 2); and (ii) the transactional or "message-oriented" (Brown and Yule, 1983: 13) function, whose main goal is "the transference of information" in order to "communicate [the] message rather than to be nice to the listener" (13). As stated previously, both ingredients need to be combined in order to acquire the best and most proficient results in communication.

It is in this linguistic arena that politeness theory becomes crucial to the interactional situation of communication. However, it might be convenient to get familiar with the concept of 'politeness' before diving into its theoretical framework.

It is broadly thought that the use of formal language in instances such as 'Would you be so kind as to take your seats?' is more polite than, for instance, 'Take your seats, will you?'. Nonetheless, there are certain occasions where the latter seems more appropriate'. From such a perspective, modern dictionaries have included in the traditional definition of politeness a new aspect concerning the hearer's perception and reaction. For instance, in the entry on "politeness" in the Cambridge Dictionary, the first definition listed indicates that

1 According to the sociolinguist Dell Hymes, 'appropriateness' "is lumped under the heading of performance, and, correspondingly, acceptability ... [It refers to] the required sense of relation to contextual features" (Pride and Holmes, 1987: 285). 
this term refers to the "behaviour that is socially correct and shows understanding of and care for the other people's feelings". Following this line, it could be concluded that "to be polite is to abide by the rules of the relationship" (Fraser and Nolen 1981: 96) and, therefore, being impolite does not correspond to the use of informal language, but to "any violation of the terms of the conversational contract ${ }^{2}$ ", thus depending on the contextual judgement of the hearer. De facto, "no sentence is inherently polite or impolite", since "there is some kind of a continuum of politeness rather than politeness being a dichotomous notion" (97).

The concept of 'politeness' as the "performance of redressive action to minimize face threat" (Spencer-Oatey 2008: 334) is first presented in Brown and Levinson's seminal work Politeness: Some Universals in Language Use (1987), which meant a remarkable breakthrough in the linguistic panorama of the late 1980s.

Moreover, together with politeness, the notion of face is strongly profiled in Brown and Levinson's work. Specifically, the term 'face' refers to "the public self-image that every member wants to claim for himself [or herself], ... something that is emotionally invested, and that can be lost, maintained, or enhanced, and must be constantly attended to in interaction" (61). These authors categorically assert that, despite the fact that the notion of face might differ culturally, "the mutual knowledge of members' public self-image or face, and the social necessity to orient oneself to it in interaction, are universal" (62).

Additionally, Brown and Levinson distinguish between 'positive face' and 'negative face'. The former consists of "the need to be accepted, even liked, by others, to be treated as a member of the same group, and to know that his or her wants are shared by others" (Yule 2014: 62), while the latter is concerned with "the need to be independent, to have freedom of action, and not to be imposed on by others" (61). Both alternatives correspond to different ways of lessening the "face threatening acts" (henceforth FTAs), i.e. acts that "represent a threat to [someone] ... regarding self-image" (61). These acts, nonetheless, are aggravated or alleviated by three factors:

First is the social distance [D] between speaker and hearer: the less socially familiar two people are, the greater the potential face threat of a communicative act between them. Second is the power $[\mathrm{P}]$ or status of the hearer relative to the speaker: the more power a hearer has compared to the speaker, the greater the face threat. Third is the rank [R] or degree of imposition (cost to negative and positive face) intrinsic to a particular act ... These three are assumed to mediate all other influences on the seriousness of an FTA. (Craig et al. 1986: 440-41)

\subsection{Strategies}

In the course of communication, the speaker needs to make a linguistic and pragmatic decision: whether to avoid doing the FTA or to employ specific strategies depending on his/her wants in order to lessen the threat (see Figure 1).

According to Brown and Levinson (1987), if an agent decides to perform the FTA, he/ she has two plausible options: to go 'on record' or 'off record'. The former has to do with

2 According to Fraser and Nolen (1981), the conversational contract is the agreement between the speaker and the hearer "to readjust what rights and what obligations they hold toward each other" (94). 
the speaker's directness of intention, where "it is clear to participants what communicative intention led the actor to do [X]" (68). In contrast, going 'off record' (represented in Figure 1 as number 4) means to utter statements that lack accuracy, thus including "all kinds of hints as to what a speaker wants or means to communicate, without doing so directly, so that the meaning is to some degree negotiable" (69). In the latter, Pragmatics plays a crucial role. Thus, by way of illustration, consider the utterance 'Oh, it's so cold in this room!'. If, upon hearing it, the hearer closes the window, it could be said that more has been communicated than what was actually said, since the hearer has been successful in guessing that the utterance was meant to be a request.

By going 'on record', an actor might perform the FTA "without redressive action" (or baldly) or "with redressive action". The first strategic choice proposed by Brown and Levinson deals with "the most direct approach, using imperative forms, known as bald on record. The other person is directly asked for something" (Yule 2014: 63). This straightforwardness could be related to Grice's "Cooperative Principle of Conversation" (1991), which is constructed upon four subcategories known as 'maxims', as shown in Table 1 .

The Cooperative Principle: Makeyour conversational contribution such as is required, at the stage at which it occurs, by the accepted purpose or direction of the talk exchange in which you are engaged.

\section{The maxims:}

Quantity

1. Make your contribution as informative as is required (for the current purposes of the exchange).

2. Do not make your contribution more informative than is required.

Quality

1. Try to make your contribution one that is true.

1.1 Do not say what you believe to be false.

1.2 Do not say that for which you lack adequate evidence.

\section{Relation}

1. Be relevant.

Manner

1. Avoid obscurity of expression.

2. Avoid ambiguity.

3. Be brief.

4. Be orderly.

Table 1. The Cooperative Principle (taken from Grice 1991: 26-27).

The second and third strategic alternatives include a 'redressive action', defined by Brown and Levinson as the following:

[The] action that 'gives face' to the addressee, that is, that attempts to counteract the potential face damage of the FTA by doing it in such a way, or with such modifications or additions, that 
indicate clearly that no such face threat is intended or desired, and that [the speaker] in general recognizes [the addressee's] face wants and himself [or herself] wants them to be achieved. (Brown and Levinson 1987: 69-70)

Therefore, depending on the orientation of the speaker's 'face saving act', there would be two feasible options:

A face-saving act which is oriented to the person's negative face will tend to show deference, emphasize the importance of the other's time or concerns, and even include an apology for the imposition or interruption. This is also called negative politeness. A face-saving act which is concerned with the person's positive face will tend to show solidarity, emphasize that both speakers want the same thing, and that they have a common goal. This is also called positive politeness. (Yule 2014: 62)

The fourth strategic choice, 'Off record', is focused on the hearer's task to infer what is hidden behind the indirectness of the speaker's utterance. In this case, Grice's Maxims are normally violated.

The fifth and last strategic variety, 'Don't do the FTA', is simply that the speaker prefers to say nothing, and by doing so, s/he is avoiding the FTA. As Yule (2014) has put it, "many people seem to prefer to have their needs recognized by others without having to express those needs in language" (62). However, this 'say nothing' alternative might or might not be successful, since the addressee is not given an explicit request and, therefore, he/she may not recognize it as such. If s/he does, it is because once again Pragmatics has been an essential aspect facilitating communication.

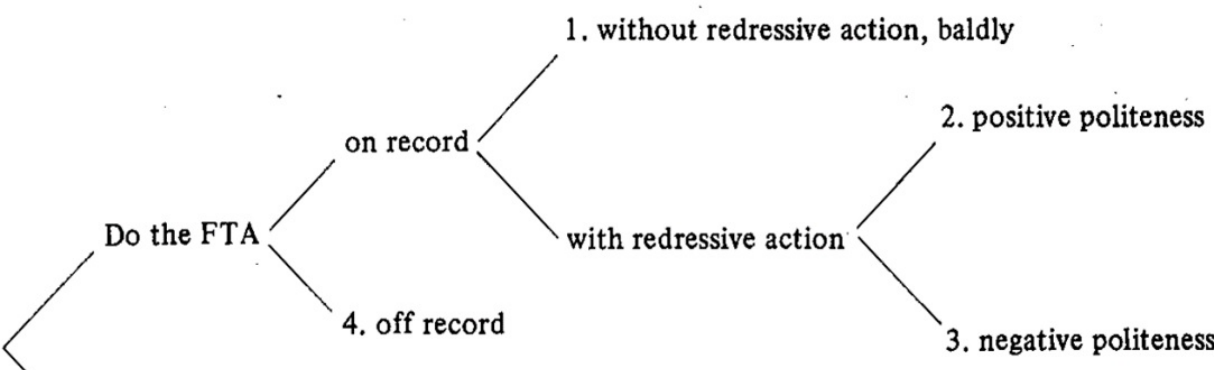

5. Don't do the FTA

Figure 1. Possible strategies for doing FTAs (taken from Brown and Levinson 1987: 69). 


\subsection{Linguistic Realizations of the Rtrategies in Pride and Prejudice With Special Wocus on Wequests}

Once the theoretical background about politeness theory and each of its strategies have been outlined, I now turn to their different linguistic realizations, as these are found in Jane Austen's masterpiece Pride and Prejudice, with special focus on requests.

\subsubsection{Bald on Record}

The bald-on-record strategy, as indicated in section 3.1 Strategies, is directly connected with Grice's Maxims (see Table 1), which "define for us the basic set of assumptions underlying every talk exchange" (Brown and Levinson 1987: 95). Nonetheless, it should be emphasized that it is not required that all utterances should meet these circumstances, since "the majority of natural conversations do not proceed in such a brusque fashion at all". It is in this context that politeness takes the role "to give some attention to face".

According to Brown and Levinson, there are certain factors which favour the speaker's need to use this strategy:

The prime reason for bald-on-record usage may be stated simply: in general, whenever S [speaker] wants to do the FTA with the maximum efficiency more than he wants to satisfy H's [hearer] face, even to any degree, he will choose the bald-on-record strategy. There are, however, different kinds of bald-on-record usage ... [depending on S's wants]: ... those where the face threat is not minimized, where face is ignored or is irrelevant; and those where in doing the FTA baldly on record, S minimizes face threat by implication. (Brown and Levinson 1987: 95)

Therefore, the main linguistic realization that stands as the fundamental depiction of the bald-on-record strategy is the imperative form, which can be accompanied by some words or expressions known as "mitigating devices"3, such as 'please', 'pray', or 'would you?'. This can be clearly seen in the following passage (1) from Pride and Prejudice, where Caroline does the FTA without redressive action using a mitigating device ('Pray'), and therefore she is lessening Darcy's face threat by implication:

(1) "Pray tell your sister that I long to see her" (Austen 2016: 47).

The other bald-on-record usage, as previously mentioned, has to do with the lack of attention to the hearer's face. This could be instantiated by the following passage (2), which corresponds with one of the climactic scenes of the novel, when Elizabeth refuses Mr Collins' proposal. In this case, the speaker tends to use the imperative form since she does not care about the hearer's face, she just wants to be clear by going baldly:

"I do assure you, Sir, that I have no pretension whatever to that kind of elegance which consists in tormenting a respectable man. I would rather be paid the compliment of being believed sincere. I thank you again and again for the honour you have done me in your proposals, but to accept them is absolutely impossible. My feelings in every respect forbid it. Can I speak plainer? Do

3 A mitigating device is for current purposes an "expression used to soften an imposition" (Yule, 2014: 131). 
not consider me now as an elegant female intending to plague you, but as a rational creature speaking the truth from her heart" (Austen 2016: 109; emphasis added).

The analogous relation between bald-on-record strategy and imperatives tempts to mix both terms. In this connection, it is particular instructive to bring to the foreground the following observation made in Yule (2014):

Imperative forms are often used by close familiars without being interpreted as commands. Examples would be a friend offering something to eat ... There are, consequently, some social circumstances where using a direct command as a bald on record expression is considered appropriate among social equals. However, generally speaking, bald on record expressions are associated with speech events where the speaker assumes that he or she has power over the other $\ldots$ and can control the other's behavior with words. (63-64)

The following excerpt (3) could be indeed misinterpreted as a bald-on-record strategy since it is uttered through an imperative form; nonetheless, due to the fact that both characters are relatives, it would be considered as a direct command instead. Specifically, Mr Bennet tells Mrs Bennet:

(2) "My dear, ... I have two small favours to request. First, that you will allow me the free use of my understanding on the present occasion; and secondly, of my room. I shall be glad to have the library to myself as soon as may be" (Austen 2016: 113).

\subsubsection{Positive Politeness}

Contrary to the bald-on-record strategy, where there is no redressive action, positive politeness shows an interest on the hearer's face and a desire to satisfy it. This on record strategy indeed "leads the requester to appeal to a common goal, and even friendship" (Yule 2014: 64). In terms of its linguistic realizations, Brown and Levinson (1987) note:

The linguistic realizations of positive politeness are in many respects simply representative of the normal linguistic behaviour between intimates, where interest and approval of each other's personality, presuppositions indicating shared wants and shared knowledge, implicit claims to reciprocity of obligations or to reflexivity of wants, etc. are routinely exchanged. Perhaps the only feature that distinguishes positive-politeness redress from normal everyday intimate language behaviour is an element of exaggeration; this serves as a marker of the face-redress aspect of positive-politeness expression, by indicating that even if S [the speaker] can't with total sincerity say 'I want your wants', [s/] he can at least sincerely indicate 'I want your positive face to be satisfied'. (101)

This direct relation to normal linguistic behaviour, which is what "gives the linguistics of positive politeness its redressive force" (103), is illustrated by the fifteen different outputs proposed by Brown and Levinson (1987) in which positive politeness may occur (see Figure 2).

Jane Austen's novel contains at least three linguistic realizations regarding the positive politeness strategy. For instance, Mr Collins' proposal to Elizabeth, which occupies almost 
an entire chapter, exemplifies what is labelled in Figure 2 as " 3 . Intensify interest to H [the hearer]". Mr Collins' main intention, as shown in (4), is to be accepted by the young woman and he tries that by listing the reasons why she should marry him in an attempt to call Elizabeth's attention:

(3) "Almost as soon as I entered the house I singled you out as the companion of my future life. But before I am run away with by my feelings on this subject, perhaps it will be advisable for me to state my reasons for marrying ... First, I think it a right thing for every clergyman in easy circumstances (like myself) to set the example of matrimony in his parish. Secondly, that I am convinced it will add very greatly to my happiness; and thirdly - which perhaps I ought to have mentioned earlier, that it is the particular advice and recommendation of the very noble lady whom I have the honour of calling patroness ... The fact is, that being, as I am, to inherit this estate after the death of your honoured father, ... I could not satisfy myself without resolving to chuse [sic] a wife from among his daughters ... This has been my motive, my fair cousin, and I flatter myself it will not sink me in your esteem. And now nothing remains for me but to assure you in the most animated language of the violence of my affection". (Austen 2016: 106-07)

However, by using positive politeness strategy as a face-saving act, the speaker's wants may be at risk of suffering a refusal. This could be demonstrated in the following passage (5), where Mr Darcy uses strategy 10 (see Figure 2) in order to make his request to Elizabeth:

(4) “"Let me call your maid. Is there nothing you could take, to give you present relief? - A glass of wine; - shall I get you one? - You are very ill."

"No, I thank you;" she replied, endeavouring to recover herself" (278).

Offers and promises are the most typical depiction of positive politeness strategy since “even if they are false ... they demonstrate S's [the speaker's] good intentions in satisfying H's [the hearer's] positive-face wants" (Brown and Levinson 1987: 125).

Another strategy that can be found in Pride and Prejudice concerning positive politeness is related to the inclusion and cooperation of both conversational actors (speaker and hearer) into the development of the action, which is numbered as 12 in Figure 2 and could be exemplified in (6):

(5) “'My dear Madam,' replied he, 'let us be for ever silent on this point. Far be it from me ... to resent the behaviour of your daughter'” (Austen 2016: 115).

Yule (2014) also recognises this latter strategy as a way of "emphasizing closeness between speaker and hearer", defining it as a "solidarity strategy" that "will be marked via inclusive terms such as 'we' and 'let's"' (65). 


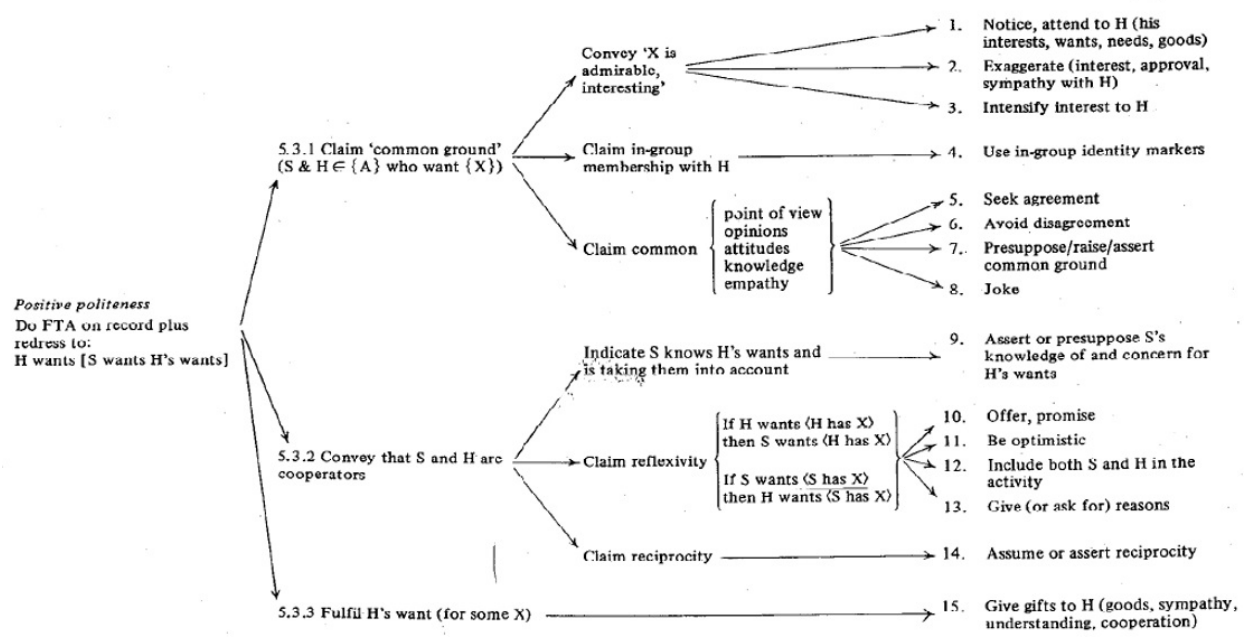

Figure 2. A taxonomy of positive politeness strategies (taken from Brown and Levinson 1987: 102).

\subsubsection{Negative Politeness}

Speakers may utter their request by using negative politeness in which his/her facesaving act is mainly oriented to show deference towards the hearer's face. Due to their similar characterization, "deference" and "politeness" are sometimes intermingled, since both are "associated with an activity or with an utterance and not with a sentence, per se" (Fraser and Nolen 1981: 97). However, a differentiation between both terms should be made mainly due to the fact that "deference is not the same as politeness, since deference is the conveying of relative status, but the inappropriate use of deference can result in an impolite utterance" (98).

After diving into the linguistic realizations of negative politeness, it is worth addressing a few lines to the explanation of what Yule calls "a deference strategy" (66):

It can be the typical strategy of a whole group or just an option used on a particular occasion. A deference strategy is involved in what is called 'formal politeness'. It is impersonal, as if nothing is shared, and can include expressions that refer to neither the speaker nor the hearer (for example, 'Customers may not smoke here, sir'). The language associated with a deference strategy emphasizes the speaker's and the hearer's independence, marked via an absence of personal claims. (Yule 2014: 66)

As Brown (1980) points out, strategies concerning negative politeness "are essentially avoidance-based, and consist in assurances that the speaker recognizes and respects the addressee's negative face and will not ... interfere with his or her freedom of action" (116). Negative politeness is, indeed, "the heart of respect behaviour, just as positive politeness is the kernel of 'familiar' and 'joking' behaviour” (Brown and Levinson 1987: 129). 
Regarding the linguistic realizations of negative politeness (see Figure 3), it is worth highlighting that, contrary to positive politeness whose outputs are forms for minimizing the hearer's face threat, negative politeness' outputs are "all forms useful in general for social 'distancing"' (Brown and Levinson, 1987: 130). These linguistic realizations are "conventional indirectnesses, hedges on illocutionary force, polite pessimism (about the success of requests, etc.), the emphasis on H's [the hearer's] relative power".

The following passage of Pride and Prejudice (7) depicts the most usual form concerning the negative politeness strategy: a request for permission "containing a modal verb" (Yule, 2014: 64), shown as 5.4.1 "Be direct" in Figure 3:

(7) “Can I have the carriage?” said Jane.

"No, my dear, you had better go on horseback, because it seems likely to rain; and then you must stay all night" (Austen 2016: 30).

Following this strategy, it is also common to find "questions that seem to ask for permission to ask a question", such as the following request (8) made by Mr Darcy:

(8) “May I ask to what these questions tend?" (Auste, 2016: 94).

Although the request in (8) could be denied, the way it is uttered seems to minimize the negative impact that employing a bald-on-record strategy would provoke.

Strategy number 2 "Question, hedge” (see Figure 3) is deployed in (9), where Mr Darcy asks Elizabeth to dance using a hedge"

(9) “Do not you feel a great inclination, Miss Bennet, to seize such an opportunity of dancing a reel?" (Auste, 2016: 51; emphasis added).

By using the negated hedge "Do not you feel a great inclination...?”, Mr Darcy's request is being softened and turned into a polite request which prompts Elizabeth's acceptance of the proposition.

Another linguistic realization of negative politeness that could be found in Pride and Prejudice is the one represented by number 3 "Be pessimistic" in Figure 3, which is mainly based on "explicitly expressing doubt that the conditions for the appropriateness of S's [the speaker's] speech act obtain" (Brown and Levinson 1987: 173), as shown in (10):

(10) "You must, therefore, pardon the freedom with which I demand your attention; your feelings, I know, will bestow it unwillingly, but I demand it of your justice" (Auste, 2016: 198; emphasis added).

In this case, Mr Darcy is taking for granted that his request will cause a negative impact on Elizabeth's face in order to provoke just the opposite reaction.

4 A hedge is for current purposes "a particle, word, or phrase that modifies the degree of membership of a predicate or noun phrase in a set” (Brown and Levinson, 1987: 145). 


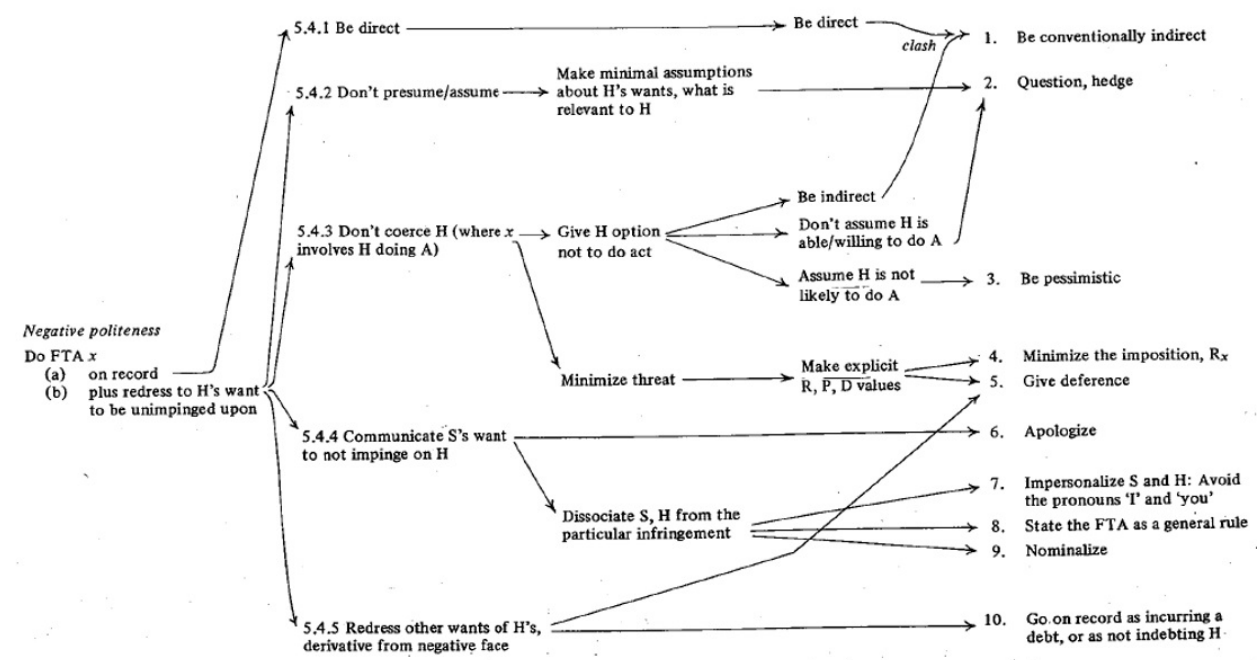

Figure 3. A taxonomy of negative politeness strategies (taken from Brown and Levinson 1987: 131).

\subsubsection{Off Record}

The last choice proposed by Brown and Levinson when performing an FTA is going 'off-record', which is chosen whenever "a speaker wants to do an FTA, but wants to avoid the responsibility for doing it", thus "[leaving] it up to the addressee to decide how to interpret it" (1987: 211). Such off-record strategy deals with what is known as 'indirect speech acts', i.e. "whenever there is an indirect relationship between a structure and a function" (Yule 2014: 55). It is in this context where the term 'inference'5 plays a fundamental role: the hearer's main task is to infer what is hidden behind the indirectness of the utterance.

There is, according to Brown and Levinson (1987), a "two-stage process" that permits a suitable comprehension of an indirect speech act: "(i) a trigger serves to notice to the addressee that some inference must be made; and (ii) some mode of inference derives what is meant (intended) from what is actually said, this last providing a sufficient clue for the inference" (211). Following Figure 4, the main signal of the hearer's need to make an inference is the violation of any Gricean Maxim (see Table 1). Thus, by way of illustration, consider the following passage (11) from Pride and Prejudice:

(11) "My dear Mr Bennet", said his lady to him one day, "have you heard that Netherfield Park is let at last?"

Mr Bennet replied that he had not.

5 According to Yule (2014), 'inference' refers to "the listener's use of additional knowledge to make sense of what is not explicit in an utterance" (131). 
"But it is", returned she; "for Mrs Long has just been here, and she told me all about it."

Mr Bennet made no answer.

"Do not you want to know who has taken it?" cried his wife impatiently.

"You want to tell me, and I have no objection to hearing it."

This was invitation enough.

"Why, my dear, you must know, Mrs Long says that Netherfield is taken by a young man of large fortune from the north of England; that he came down on Monday in a chaise and four to see the place, and was so much delighted with it that he agreed with Mr Morris immediately; that he is to take possession before Michaelmas, and some of his servants are to be in the house by the end of next week."

"What is his name?"

"Bingley."

"Is he married or single?"

"Oh! single, my dear, to be sure! A single man of large fortune; four or five thousand a year. What a fine thing for our girls!'

"How so? how can it affect them?"

"My dear Bennet", replied his wife, "how can you be so tiresome!

You must know that I am thinking of his marrying one of them" (Austen, 2016: 3-4; emphasis added).

This excerpt performed by Mr and Mrs Bennet clearly exemplifies the 'off-record' strategy, and more concretely strategies number 1. "Give hints" and number 2. "Give association clues" (see Figure 4). First, it should be said that by uttering "have you heard that Netherfield Park is let at last?" or "Do not you want to know who has taken it?", Mrs Bennet is violating the Relevance Maxim, since she is not being explicitly relevant and she is trying to invite Mr Bennet "to search for an interpretation of the possible relevance" (Brown and Levinson 1987: 213). Therefore, Mrs Bennet's questions or triggers turns $\mathrm{Mr}$ Bennet's answers into a way of saying 'go ahead' to his wife, and therefore, they could be considered as 'pre-requests' ${ }^{6}$. Indeed, Mrs Bennet continues giving clues to her husband so

6 A pre-request is for current purposes an "utterance before a request to check if a request can be made" (Yule 2014: 133). 
as to make him aware of her intentions, i.e. to marry one of her daughters: "Oh! Single, my dear, to be sure! A single man of large fortune ... What a fine thing for our girls!"

However, as stated in section 3.1 Strategies, by going 'off-record', the speaker's success is not guaranteed; in fact, Mrs Bennet decides to go 'bald-on-record' at the end of the passage so as to assure her request is understood: "You must know that I am thinking of marrying one of them".

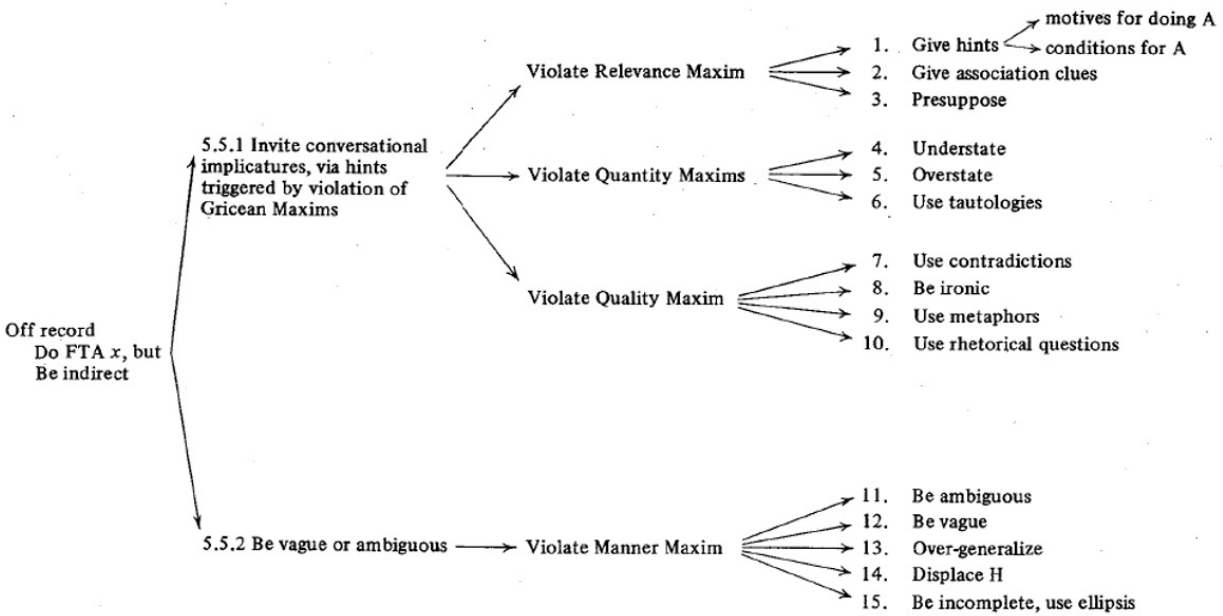

Figure 4. A taxonomy of off record strategies (taken from Brown and Levinson 1987: 214).

\section{TOWARDS A CONSTRUCTIONIST, CONTRASTIVE ANALYSIS OF REQUESTS IN PRIDE AND PREJUDICE}

\subsection{Construction Grammar(s): Origins, Precursors, and Cross-linguistic Influence}

The family of Construction Grammar(s) (henceforth $\left.\mathrm{CxG}(\mathrm{s})^{7}\right)$ finds its origins in the "theorizing of Charles Fillmore and his students and colleagues, [including Professor Paul Kay], at the University of California at Berkeley in the early 1980s" (Fried and Östman 2004: 1). This grammatical approach originally stem from Case Grammar, i.e. "the caserole based approach which Fillmore successfully pursued in a number of articles in the late

7 In contrast to Generative Grammar, Construction Grammar should be considered a family of constructionist approaches (CxG(s)). This idea is defended by Goldberg (2013), who argues that although "certain mainstream generative grammar frameworks share the basic idea that some type of meaning is directly associated with some type of form" (30), these generative accounts "emphasize rough paraphrases instead of speakers' detailed construals of situations. Thus, neither the syntax nor the semantics is akin to that adopted by constructionists". Goldberg also adds that "researchers tend to find constructionist approaches much more interesting, accessible, and useful" (31). 
1960s" that not only helped in the process of "making a semantic level of analysis more discernable [sic] through case roles, later known as semantic roles", but also in the deviation "from traditional transformational-generative approaches of the 1960s in that it made a point of reinstating the importance of grammatical functions in syntax" (2). Together with Case-Grammar, Fillmore's Frame Semantics, which will be carefully examined in section 4.1.1 Boas' Proposal and Fillmore's Frame Semantics, marked a substantial development within the field of $\mathrm{CxG}$.

Another pivotal figure in $\mathrm{CxG}$ was the American linguist George Lakoff with the Gestalt Grammar in the late 1970s, a model which is defined by Fried and Östman (2004) as an "experiential approach to syntax based on the view that the grammatical function of a sentence constituent holds only in relation to a particular sentence type as a whole" (3).

What lies behind the core meaning of $\mathrm{CxG}$ is the focus on the notion of "construction' as the symbolic unit that combines form (i.e. syntactic, morphological, and phonological properties) with conventionalized meaning (i.e. semantic, pragmatic, and discoursefunctional properties) (Boas 2010: 3), as illustrated in Figure 5.

One of the reasons that has facilitated the impetus of constructionist approaches in the present-day linguistic scenario is that "analytic and representational tools ... can be successfully applied to the description, analysis, and explanation of diverse linguistic phenomena in a variety of languages" (Boas 2010: 4).

Nonetheless, at the same time, there has been a lack of widespread interest in "arriving at cross-linguistic constructional generalizations" among different languages. According to Boas (2010), the reasons for this are: (i) historical coincidence, due to the fact that the research focus of $\mathrm{CxG}$ had been mainly on English and because of the only-onelanguage focus, research on the cross-linguistic nature of $\mathrm{CxG}$ has been somehow ignored when following this methodology with other languages, thus leaving cross-linguistic generalizations aside; and (ii) the view that constructions per se are language-specific, mostly defended by William Croft in his Radical Construction Grammar (2001).

William Croft suggested that "all aspects of the formal representation of grammatical structure are language-particular" (Boas 2010: 5) and proposed an alternative to Universal Grammar where "the universals of language are found in systematic structure and in symbolic structure, that is, the mapping between linguistic function and linguistic form" (Croft 2001: 61).

8 As Boas (2010) points out, Goldberg (2006) defined 'constructions' as "any linguistic pattern ... [whose] form or function is not strictly predictable from its component parts or from other constructions recognized to exist" (3). 


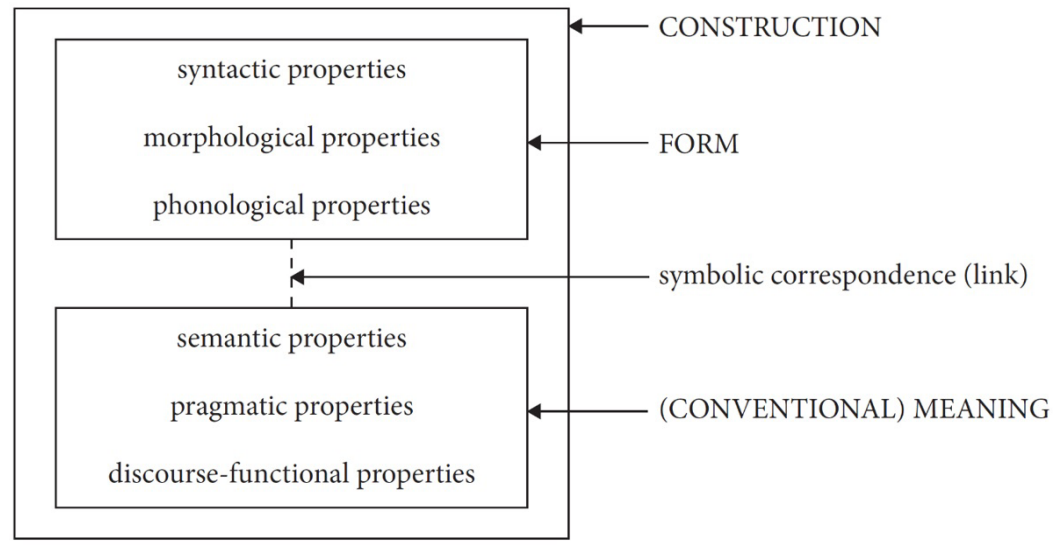

Figure 5. The symbolic structure of a construction (taken from Boas 2010: 3).

Boas (2010) considers Croft's proposal "too coarse-grained" due to his "reliance on relatively small amounts of data from each language" (Boas 2010: 6) and suggests a "more careful bottom-up approach" (7), which will be examined in the following section.

\subsubsection{Boas' Proposal and Fillmore's Frame Semantics}

Instead of embracing more than two languages, as Croft firstly did, Boas considers that an approach that "only compares and contrasts constructions between pairs of languages" (Boas 2010: 7) is a more accurate way in the process of creating cross-linguistic constructional generalizations.

This way of analysing and comparing pairs of languages emerges from contrastive linguistics, which dates back to the 1940s with Charles Carpenter Fries' Teaching and Learning English as a Foreign Language (1945), mainly concerned with language pedagogy. In much the same vein, Boas (2010) enhances the importance of Fillmore's Frame Semantics within contrastive analysis, which qualifies as "an intuitive method of elaborating the analysis of form-meaning relationships by focusing on lexical semantic issues that are relevant to grammatical strucutre" (8).

In regards to cross-linguistic constructional comparisons, Frame Semantics "studies the syntactic properties of words by asking how their semantic properties are given syntactic form" (Boas, 2010: 8). Frame Semantics had its major success with the creation of the FrameNet project, a web which "identifies and describes semantic frames and analyzes the meanings of words by directly appealing to the frames that underlie their meaning".

\subsection{Exploring Pride and Prejudice from a Contrastive, Frame-semantic Analytical Perspective}

In order to focus this research towards a cross-linguistic perspective, Spanish and English verbs that evoke the REQUEST frame and that appear in some of the previous 
sections of this paper are going to be analysed from the FrameNet project's perspective, thus establishing some relationships between both languages. For this purpose, two websites are going to be used: the English-based FrameNet project, and the Spanish-based FrameNet project $^{9}$, the latter developed by the Spanish professor of linguistics Carlos Subirats.

To illustrate how the FrameNet project works, and in the light of a constructionist and contrastive analysis of requests in Pride and Prejudice, it is instructive to consider the following quote from Boas (2010):

Based on corpus evidenced, FrameNet entries provide for each lexical unit (a word in one of its senses) the following information: (1) a definition of the frame which it evokes, together with a list of all Frame Elements found within the frame; (2) a realization table summarizing the different syntactic realizations of Frame Elements; (3) a summary of all valence patterns found with the lexical unit, i.e. "the various combinations of frame elements and their syntactic realizations which might be present in a given sentence". (8)

Since the first sections of this paper have been devoted to the role of requests in Pride and Prejudice in relation to the Politeness Theory, it is worth dwelling on the REQUEST frame $^{10}$. As the previous quote states, the FrameNet project firstly provides a definition of the lexical unit. In this case, the REQUEST frame is defined as a situation in which a SPEAKER asks an ADDRESSEE for something, or to carry out some action. It represents a kind of situation in which different types of relationships hold between "Frame Elements" (FEs), which are defined as "situation-specific semantic roles" (Boas 2010: 8). The FEs that form the core of the REQUEST frame in English are the following:

a. The FE ADDRESSEE can either occur as (i) an NP Object (usually with a following complement clause), e.g. "The child implored her parents to let her stay up late"; or (ii) as a PP Complement of verbs or nouns, e.g. "I pleaded with the bus driver to let me on without paying".

b. The FE SPEAKER is, as in other communication frames, an External Argument, e.g. "The judge ordered the plaintiff to return the money".

c. The FE MEDIUM is the physical entity or channel used to transmit the Message. It is frequently expressed as a PP Complement headed by "on" or "in", e.g. "The parents of the missing child made an appeal on television".

d. The FE MESSAGE is the content of the request that can be expressed (i) as a quote, e.g. " "I'd like an extension", begged Pat"; (ii) in a finite or non-finite clausal Complement, e.g. "Pat begged them to reconsider"; (iii) an NP Object, e.g. "The students requested an extension of the deadline"; or (iv) PP Complement, e.g. "The offender begged for clemency".

9 For a full version of both projects, the reader is referred to the English-based website at https://framenet2. icsi.berkeley.edu/fnReports/data/frameIndex.xml?frame=request and the Spanish-based website at http:// sfnlinux1.uab.es:8080/farina-web//LUIndex.html.

10 It is worth noting that all examples used in this subsection are taken from the two FrameNet projects previously mentioned. 
In the case of the Spanish FrameNet, the FEs of the REQUEST frame are very similar to the English ones, although some differentiations need to be made:

a. The FE ADDRESSEE can either occur as (i) an Indirect Object of verbs or nouns with support verbs"11, e.g. "Le suplicó a la todopoderosa Agencia Tributaria que no le embargasen su hacienda"; or (ii) as a Prepositional Object of nouns without supporting verbs, e.g. "Presenté una solicitud a la Agencia Tributaria para que me dejaran en paz".

b. The FE MEDIUM is a non-core FE in Spanish, but behaves in the same way that English does, since it is frequently expressed as a PP Complement headed by por or en: e.g. "La presidenta hizo un llamamiento por televisión dirigido a todas las ciudadanas de la nación".

The REQUEST frame is evoked by several lexical units or "semantically-related words" (Boas 2010: 8) that obviously differ from one language to another. Table 2 shows some of the different lexical realizations of the REQUEST frame in English and Spanish with their corresponding grammatical category in brackets ${ }^{12}$. Nonetheless, it should be said that the following are realizations extracted from the novel and, therefore, they concern the main subject to study:

\begin{tabular}{|ll|}
\hline English-based model & Spanish-based model ${ }^{13}$ \\
\hline Ask (v) & Exigir (v) \\
Demand (v) & Ordenar (v) \\
Order (v) & Pedir (v) \\
Request (v) & Preguntar (v) \\
Tell (v) & Solicitar (v) \\
\hline
\end{tabular}

Table 2. Lexical units of the REQUEST frame in Pride and Prejudice (taken from the Spanish and English FrameNets, listed in alphabetical order).

Once the most representative lexical units have been listed, I now turn to the analysis of four requests mentioned in section 3. Politeness Theory that include verbs evoking the REQUEST frame with their corresponding translation into Spanish. To this end, the syntactic

11 A support verb is, according to the FrameNet project, a "semantically neutral verb that turns a target noun into a verb phrase-like predicate and allows for the expression of a frame element as its subject": e.g. "make" in "make a decision" or "say" in "say a prayer".

12 It is worth stressing that Table 2 contains some verbs whose meaning may vary depending on the domains or frameworks in which they occur. For the purpose of this paper, verbs such as "ordenar" should be regarded here as the action of expressing an order.

13 The present list has been taken from the Spanish-based FrameNet project. Nonetheless, it should be pointed out that there are other Spanish lexical units that may appear in the REQUEST frame beyond those specified here, such as "obligar" or "decir", among others. 
realizations of the FEs are specified together with the target word $\left({ }^{\mathrm{TGT}}\right)$, which is the word that evokes the semantic frame (Boas 2010: 8).

Sentences (1a) and (1b) illustrate that the verb "tell"14 behaves similarly in both languages: in terms of syntactic realizations, one can find an ADDRESSEE as Indirect Object ("your sister" and "a su hermana") and a MESSAGE realized as a finite nominal clause functioning as Direct Object ("that I long to see her" and "que deseo verla"). In regard to the SPEAKER, it should be treated as a 'constructional null instantiation' $\left(\mathrm{CNI}^{15}\right)$ since its imperative nature requires this omission. Therefore, this imperative utterance occurs in the following syntactic valence ${ }^{16}$ or pattern: TGT ${ }_{+}$ADDRESSEE ${ }_{+}$MESSAGE.

(1a) "Pray tell TGT $\left[_{\text {ADDREsSEE }}\right.$ your sister] $\left[_{\text {MesSAGE }}\right.$ that I long to see her]" (Austen 2016: 47).

(1b) "Por favor, dígale TGT $\left[_{\text {ADDResse }}\right.$ a su hermana] $\left[_{\text {MeSSAGE }}\right.$ que deseo verla]" (Rodríguez 2018: 60).

The next pair of sentences bring to focus the target verb "request", glossed as 'asking politely or formally in an effort to bring something about'. Once again it can be seen that the Spanish and English syntactic realizations differ in virtually no respect: the syntactic realizations are ADDRESSEE as Indirect Object, and MESSAGE ${ }_{1}$ and MESSAGE 2 as finite nominal relative clauses inside the Direct Object. One remarkable difference is the omission of the SPEAKER in the Spanish version, while present on the English one ("I"). The syntactic valence or pattern would be ADDRESSEE + SPEAKER $_{+}$TGT $_{+}$MESSAGE $_{1+}$ MESSAGE $_{2}$.

(3a) “ $\left[_{\text {ADDRESSEE }}\right.$ My dear $], \ldots\left[_{\text {SPEAKER }} \mathrm{I}\right]$ have two small favours to request ${ }^{\text {TGT }}:\left[_{\text {MESSAGE }}\right.$ first, that you will allow me the free use of my understanding on the present occasion];

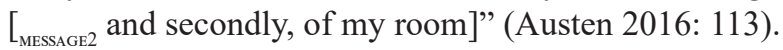

(3b) " $\left[_{\text {ADDRESSEE }}\right.$ Querida mía], ... tengo dos pequeños favores que pedirte ${ }^{\text {TGT: }}$ [ $_{\text {MESSAGE1 }}$ que en esta ocasión me permitas hacer libre uso, primero, de mi entendimiento], $\left[_{\text {MESSAGE2 }}\right.$ y segundo, de mi biblioteca]" (Rodríguez 2018: 133).

Sentences (8a) and (8b) illustrate the target unit "ask" in the sense of "requesting someone to do or give something'. In terms of syntactic valence, the two languages have in common a MESSAGE functioning as the Direct Object. Regarding the SPEAKER, the Spanish translation does not include it since it could be understood from the verb tense ("Yo puedo"). Something similar happens with the ADDRESSEE, although in English it is not as evident from the context as in Spanish, where it qualifies as an instance of definite

14 Sentences (1a) and (1b) do not show the verb "tell" in the sense of 'instructing (someone) to do something'. In fact, it functions as a speech verb, although, from a conversational viewpoint, it can be interpreted as an indirect request, given an adequate supporting context.

15 See the FrameNet glossary available at www.framenet.icsi.berkeley.edu/fndrupal/glossary.

16 The word valence includes for current purposes "the word's conceptually central complements and those that a speaker may choose to introduce" (Fillmore 2012: 119). "Semantic valence information is often recorded in a notation that is similar to logic, and referred to as argument structure. Syntactic valence information is usually specified in terms of the phrase types ... and in terms of the grammatical functions" (Fillmore et al. 2003: 236). 
null instantiation $\left(\mathrm{DNI}^{17}\right)$. Therefore, the syntactic pattern of this lexical unit would be as follows: SPEAKER + TGT $_{+}$MESSAGE.

(8a) "May $\left[_{\text {SPEAKER }} \mathrm{I}\right]$ ask $^{\text {TGT }}\left[_{\text {MESSAGE }}\right.$ to what these questions tend $]$ ? $\left[_{\text {ADDRESSEE }}\right.$ DNI]" (Austen 2016: 94).

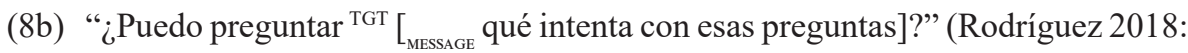
114).

The last pair of requests focuses on the target word "demand" in the sense of "asking authoritatively or brusquely'. In both cases, the MESSAGE takes the form of an NP functioning as Direct Object; nonetheless, and because of some grammatical reasons previously mentioned, the Spanish translation does not include the SPEAKER ("I") nor the ADDRESSEE ("You") since both are understood from the tense. The valence pattern would be ADDRESSEE + SPEAKER + TGT + MESSAGE.

(10a) “ $\left[_{\text {ADDRESSEE }}\right.$ You $]$ must, therefore, pardon the freedom with which $\left[_{\text {SPEAKER }} I\right]$ demand TGT [ [

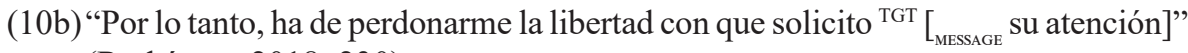
(Rodríguez 2018: 230).

After exploring how Spanish and English work in relation to the use of requests in Jane Austen's Pride and Prejudice, it could be concluded that both languages behave in a similar way. De facto, it is noticeable that for the two of them there are three main ingredients that need to be added when requesting: a speaker, an addressee, and a message. Elements such as the medium or the manner are secondary for the purpose of requesting.

Moreover, the previous contrastive, frame-semantic analysis in the light of data from the FrameNet projects in English and Spanish as the basis for the study could be seeing as a first step towards providing conclusive empirical evidence facilitating the postulation of constructional generalizations across languages, as advocated in Boas (2010) in the following terms:

Using semantic frames to describe [those] syntactic differences allows us to capture them systematically in one language, and also across languages, thus demonstrating that semantic frames are in principle a useful tool for cross-linguistic constructional analysis ... [Indeed, this procedure] offers a more fine-grained methodology that holds the promise of ultimately arriving at cross-linguistic constructional generalizations without losing sight of language-specific idiosyncrasies. (Boas 2010: 9-10)

A further outlook could be drawn from this contrastive analysis, and it has to do with the modalizing value of the verb ${ }^{18}$ in shaping the overall locutionary and illocutionary forces of the request, which could be said to hold true in both languages (Spanish and English). In

17 According to the FrameNet glossary, a definite null instantiation (DNI) is "an FE that is missing from a sentence, but whose identity is understood from the context".

18 Palmer (1986), among other grammarians, distinguished between (i) "epistemic modality” ("may", "can"), which deals with possibility, probability, etc., as in "It may rain tomorrow"; and (ii) "deontic modality" 
the light of this, some verbs explicitly encode a request (e.g. "solicitar", "pedir", "demand", "request", etc.), and others convey a command or order (e.g. "ordenar", "exigir", "order", "urge", etc.). This value, however, goes far beyond the intrinsically lexical nature of the verb: the morphosyntactic encoding of the Direct Object plays an important role in modulating the overall meaning of the resulting speech act ${ }^{19}$, regardless of which verb appears in the utterance. Therefore, regarding Givón (1980), the following two generalizations need to be brought into focus:

(i) The use of a finite nominal clause construction introduced by "that-" and/or "que-" expresses a weak manipulation on the hearer's face ${ }^{20}$.

(ii) The use of a non-finite infinitive clause construction implies a strong(er) manipulation on the hearer's face.

The first premise is clearly seen in the four pair of examples previously mentioned. More specifically, consider sentences (1a) and (3a), where the 'that'-clauses ("that I long to see her" and "that you will allow me the free use of my understanding on the present occasion; and secondly, of my room") functioning as Direct Objects are quite likely to be interpreted as requests with a polite colouring added by the use of the finite clause construction.

Weak manipulations are also emphasised by the use of different linguistic ingredients, including the 'mitigating devices' (see section 3.2.1 Bald on record) such as "Pray" in (1a), nouns and/or adjectives such as "favour" and "small" in (3a), and modal verbs like "May" in (8a). These resources further modulate the direct speech act of the request in a more polite sense, as they minimise the hearer's face threat. Indeed, if these mitigating devices are eliminated, face threat would be enhanced: "Pray tell your sister..." vs "Tell your sister...".

The relevance of the second premise regarding strong manipulation can perhaps be clearly seen if sentence (3a) is transformed into the following: "I order you to leave my room", "Te ordeno abandonar mi habitación", where the infinitival constructions have a stronger illocutionary force ${ }^{21}$ more akin to commands, thus increasing the speaker's influence on the hearer and also possibly his/her face threat.

The distinction between weak and strong manipulations could be further supported by the following examples, where the verb "tell" used in the same sense as (1a) serves as an illustration of the relevance of this constructional difference in the arena of requests. In the light of this, consider the following pair of sentences, where (a) is taken from Austen's Pride and Prejudice, and on which sentence (b) has been formulated:

a. "Tell my dear Lydia not to give any directions about her clothes" (Austen 2016: 289).

b. "Tell my dear Lydia that she should not give any directions about her clothes".

("must", "have to", "should", etc.), which includes imperatives, requests, suggestions, volitives, etc. (Salkie, 1988: 240-241).

19 A 'speech act' is for current purposes "an action performed by the use of an utterance to communicate" (Yule 2014: 134).

20 For further explanation, see section 3. Politeness Theory.

21 An 'illocutionary force' is for current purposes "the communicative force of an utterance" (Yule 2014: 130). 
On the one hand, sentence (a) follows Givón's (1980) strong manipulation in that it is made up of a non-finite infinitival construction ("not to give") that gets closer to the scope of an order or command. On the other hand, sentence (b) includes a finite nominal construction introduced by a 'that'-clause, and therefore shows a weak(er) manipulation. This constructional behaviour also occurs with the Spanish verb "decir":

c. "Di a mi querida Lydia que no encargue la confección de los trajes" (Rodríguez 2018: 327).

Sentence (c) depicts a weak manipulation construction introduced by a 'que'-clause that serves, together with the use of the mitigating adjective "querida", to minimize the hearer's face threat. Nonetheless, in Spanish it is not grammatically correct to say: *'Di a mi querida Lydia no encargar la confección de los trajes", thus being sentence (d) the appropriate way to utter the non-finite infinitival clause. Sentence (d) would be, according to Givón (1980), a case of strong manipulation closer to weak manipulation in the continuum that exists between these two, and therefore it would explain the suggestive nature of this illocutionary force:

d. "Le dijo de encargar la confección de los trajes".

Therefore, it could be argued that the REQUEST frame should be conveniently understood in both languages (English and Spanish) as a cline between both types of manipulations (weak and strong), where the prototypical request tends to be identified with the weak manipulation in both languages. This implies, among other things, that despite the lexical nature of the main verb in conjunction with the inherent meaning-form (i.e. constructional) properties of the realizations of the complements (especially direct objects, when applicable) work in tandem to shape the overall illocutionary force of the speech act.

It is worth highlighting that the constructional value of the sentence complements' realizations is not included in the FrameNet descriptions since both projects (English and Spanish) have not been fully developed yet. Nonetheless, and due to the fact that these are constructional principles, they are totally compatible with Frame Semantics in general and FrameNet in particular.

\title{
5 CONCLUSIONS
}

\begin{abstract}
"Politeness theory is a very psychological theory that cannot be tested with a speaker's words alone: it is sometimes necessary to know unspoken thoughts"
\end{abstract}

(Brown and Gilman 1989: 171).

Diving into literature through a linguistic perspective, in this case through Brown and Levinson's Politeness Theory, has enabled us to find further empirical support to demonstrate that language is the basis of not only verbal but also of the cognitive processes underlying the production and interpretation of meaning: we build words from thoughts in the same way we build thoughts from words. 
Therefore, as Brown and Gilman (1989) mention, literature offers good possibilities for the study of Politeness Theory, since it consists of speech that "is not elicited from informants but was invented by authors for purposes of their own", thus surprising analysts "into discoveries they had not envisioned". This way, the study of Pride and Prejudice from the perspective of Politeness Theory "has much in common with studying protocols of spontaneous child speech with a grammar and a theory of acquisition in mind. You do not control the flow of data. It pours over you and you must cope as best you can" (208).

With respect to the constructionist analysis of requests in Pride and Prejudice based on Fillmore's Frame Semantics, it could be argued that the morphosyntactic encoding and the semantico-pragmatic interpretation of the instances selected have shown that the encoding and the interpretation of requests in English and Spanish are almost identical, thus proving that, although differences can indeed be established among the two languages at varying levels of granularity, the semantico-pragmatic function of conveying a request goes some way towards explaining the considerable degree of convergence observed in the two languages scrutinized in this work.

\section{REFERENCES}

Austen, J. 2016. Pride and Prejudice. London: Penguin.

Boss, H. 2010. "Comparing Constructions across Languages" in Contrastive Studies in Construction Grammar. H. Boas Ed. Amsterdam: John Benjamins.

Brown, P. 1980. "How and Why Are Women More Polite: Some Evidence from a Mayan Community" in Women and Language in Literature and Society. S. McConnell-Ginet, R. Borker, \& N. Furman Ed. Oxford: Blackwell.

Brown, P. \& Levinson, S. 1987. Politeness: Some Universals in Language Usage. Cambridge University Press.

Brown, R. \& Gilman, A. 1989. "Politeness Theory and Shakespeare's Four Major Tragedies." Language in Society, 18, 2: 159-212. Accessed 14 May 2021. JSTOR: www.jstor.org/stable/4168029.

Craig, R., Tracy, K. \& SpISAK, F. 1986. "The Discourse of Requests". Human Communication Research, 12, 4: 437-468. Oxford University Press. Accessed 16 Feb 2021. DOI:10.1111/j.1468-2958.1986.tb00087.x.

Croft, W. 2001. Radical Construction Grammar. Oxford: Oxford University Press.

Fillmore, C., Johnson, C. \& Petruck, M. 2003. "Background to Framenet”. International Journal of Lexicography, 16, 3: 235-250. Oxford University Press. Accessed 10 May 2021. DOI:10.1093/ij1/16.3.235.

Fillmore, C. 2012. "Berkeley Construction Grammar" in The Oxford Handbook of Construction Grammar. Eds. T. Hoffmann \& G. Trousdale. Oxford University Press.

FisCHER, O. \& NÄNNY, M. 2001. The Motivated Sign (Iconicity in Language and Literature 2). Amsterdam and Philadelphia: John Benjamins. 
Fraser, B. \& Nolen, W. 1981. "The Association of Deference with Linguistic Form". International Journal of the Sociology of Language, 27: 93-107. Accessed 12 Feb 2021. DOI:10.1515/ijsl.1981.27.93.

Fried, M. \& Östman, J. 2004. "Historical and Intellectual Background of Construction Grammar". In Construction Grammar in a Cross-Language Perspective. M. Fried \& J. Östman Eds. Amsterdam: John Benjamins.

FrIES, C. 1945. Teaching and Learning English as a Foreign Language. Ann Arbor: University of Michigan Press.

Givón, T. 1980. "The Binding Hierarchy and the Typology of Complements". Studies in Language, 4, 3: 333-377. John Benjamins Publishing Company. Accessed 12 May 2021. DOI:10.1075/sl.4.3.03giv.

Goldberg, A. 2006. Constructions at Work. Cambridge: Cambridge University Press

Goldberg, A. 2013. "Constructionist Approaches". In The Oxford Handbook of Construction Grammar. T. Hoffmann \& G. Trousdale. Eds. Oxford University Press.

GrICE, P. 1991. Studies in the Way of Words. Harvard: Hardvar University Press.

JaKobson, R. 1960. "Linguistics and Poetics". In Style in Language. T. Sebeok. Ed. Cambridge, MA: MIT Press. 350-377.

Nolan-Grant, C. 2009.“Jane Austen's Speech Acts and Language-Based Societies.” Studies in English Literature, 1500-1900, 49,4: 863-878. Accessed 14 May 2021. JSTOR: www.jstor.org/stable/40467508.

Nolan-Grant, C. 2021. "Politeness.”. Def. N. 1. In Cambridge Dictionary. Accessed 12 February 2021. www.dictionary.cambridge.org/es/diccionario/ingles/politeness.

Pride, J.B. \& Holmes, J. 1987. Sociolinguistics: Selected Readings. London: Penguin Books.

Rodríguez, A. Translator. 2018. Orgullo y Prejuicio. By Jane Austen. Madrid: Penguin Clásicos.

Salkie, R. 1988. "F. R. Palmer, Mood and Modality. Cambridge: Cambridge University Press, 1986. Pp. XII 243.” Journal of Linguistics, 24, 1: 240-243. DOI:10.1017/ S0022226700011695.

Spencer-OAtey, H. 2008. Culturally Speaking: Culture, Communication and Politeness Theory. London: Continuum.

Watzlawick, P., Bavelas J. \& Jackson, D. 1967. Pragmatics of Human Communication: A Study of Interactional Patterns, Pathologies, And Paradoxes. New York: W. W. Norton \& Company.

Yule, G. 2014. Pragmatics. Oxford: Oxford University Press. 